\title{
Factor analysis of China's education investment and economic growth spatial effect
}

\author{
Dongdong Weng ${ }^{1}$, Xiaofang Wang ${ }^{2}$ \\ 1.Quanzhou Normal University ,Fujian,Quanzhou ,China \\ 2.Liming Vocational University,Fujian, Quanzho,China \\ email:weng28911985@163.com;email:wxf@lmu.cn
}

\begin{abstract}
- education investment is an important way to form human capital. Based on the understanding of the connotation of the education investment, investment scale, investment in education from the education quality and Education Investment Fair three aspects are selected to reflect the status of the education investment index, the equity in East, central areas of education investment in western region, the education fair resource allocation can better promote economic development. And proposed to continue to increase investment in education in various regions, and focus on colleges, to solve the problem of education investment fair.
\end{abstract}

$\begin{array}{cccc}\begin{array}{c}\text { Keywords-The } \\ \text { Education;Investment }\end{array} & \text { scale } & \text { of } & \text { investment in } \\ \text { education } & \text { quality;Education }\end{array}$
Investment Fair

\section{INTRODUCTION}

Research from our previous point of view, there are three shortcomings: first, most scholars only emphasize the education investment to economic growth, while the reverse effect of economic growth on education is seldom mentioned. Second, so far, most of the literature focuses on the quantity and scale of education investment on economic growth, without considering the effect of differences in education investment to the economic growth quality. Third, the present study with little consideration to the differences in education investment fair degree of impact on economic growth in a panel data model.

II. ANALYSIS OF FACTORS AFFECTING SPATIAL EDUCATION INVESTMENT AND ECONOMIC GROWTH

In order to further explore the influence of regional factors in different provinces and cities between education and economic growth difference, this paper selects the GDP per capita in 2007, per capita education funds, the average number of years of education, number, degree million college education Gini coefficient, while the introduction of highway mileage between 29 provinces and the capital region (not including Hainan Province, Tibet province) as the distance measure between provinces, geographically weighted model is established, the provincial cross section data in 2007, the scale of investment in education, the quality and fairness of the impact on economic growth. Data from the "China
Expressway and the highway network map.".

A. Spatial correlation test

Table ISpatial correlation test results

\begin{tabular}{c|c|c}
\hline Variables & Moran's I & $\begin{array}{c}P \\
\text { value }\end{array}$ \\
\hline LGDP & $0.5963^{*}$ & $(0.001)$ \\
\hline FU & $0.5047^{*}$ & $(0.001)$ \\
\hline AVE & $0.6903^{*}$ & $(0.001)$ \\
\hline DZ & $0.5908^{*}$ & $(0.001)$ \\
\hline GINI & $0.6586^{*}$ & $(0.001)$ \\
\hline
\end{tabular}

Illustrated by table 1, five variables of Moran 's I statistics of the $\mathrm{P}$ values are less than 0.01 , we can reject the null hypothesis, that the cross section data of each variable is significantly positive spatial correlation. So in the empirical research, it is necessary to consider the spatial factors, the following will establish a spatial econometric model to estimate the various provinces and cities in China between the education investment difference influence on economic growth.

\section{B. Establishment and analysis of geographically weighted regression model}

Through the above analysis can be seen, between provinces and regions in China due to geographical factors exist certain gap. Should use of geographically weighted regression (GWR) for further study of complex spatial variation.

There is a big gap between the scale of investment in education in various provinces in China at the present stage; provincial education investment scale has significant positive effect on economic growth, expand the scale of education investment in eastern provinces and cities to promote the role of economic growth is slightly higher than other provinces and cities.Analysis of the difference can be found between regions, promote the regional differences in per capita education funds slightly on the growth rate of per capita GDP, is the highest in Fujian Province, Zhejiang, followed by Shanghai, the per capita expenditure on education positive effect on per capita GDP relatively large areas and Guangdong, Jiangsu, Jiangxi, Jilin, Hunan, Liaoning. Different regions of the average number of years of education on the growth rate 
of per capita GDP role differences, is the highest in Guangdong Province, Guizhou, Fujian, Guangxi, Jiangxi, followed by Hunan, where there is significant effect of Shanghai, Jiangsu, Zhejiang, Anhui.

The provinces of our country higher human capital contribution rate is not highThe East, middle area million people with college degree or above with the same number of negative effects on economic development, but the contribution rate is not high, only $0.01 \%$ of the average. Our highly educated talents of all economic regions are not many, the contribution to economic growth rate is very low. China economic growth mainly depends on the material capital investment, higher human capital contribution rate is not high. Compared with the increase of education investment scale, enhancement of high-quality personnel to better promote economic development. But at present our country is in the developing countries, the investment driven, compared with developed countries, advanced human capital contribution to economic growth is not obvious, the quality of education investment is still at a low level to promote economic growth.

The education of Gene coefficient of each provinces and regions of economic growth is the reaction.Further consideration of differences between regions in the degree of educational equity, negative effect of education Gene coefficient of different provinces and cities to economic growth is different, of which the highest negative effect is the Zhejiang Province, up to -1.9969 , followed by Jilin, Heilongjiang, Liaoning, Inner Mongolia, Beijing, the lowest negative effects are Guangxi, Guangdong, Fujian, Guizhou, Chongqing. According to the provincial investment in education Gini coefficient, geographically weighted model senior high school entrance examination into the effect of geographic distance factors, so the distribution of education resources from investment in education inequality and economic growth inhibition is not completely positive correlation. This panel estimation results the conclusion is different, because of considering the impact of geographical disparities between provinces and cities on the investment in education fairness.

\section{MAIN CONCLUSIONS}

There is big gap between educational investment and economic gap between China's East, West, in various provinces and cities. The eastern provinces of the fast economic growth in the western region. At the same time, the western provinces to invest in education is backward.

Basic education and higher education has made great progress, education level was generally improve. The economically developed eastern region the average number of years of education and higher education the proportion of the population is higher than the central and western.

With the improvement of education level, declined in all regions of our country education inequality. But the economic development in the western backward educational inequality is greater than that of the eastern and central.

In every area of our country education investment and expand the scale has an important effect on the economic growth. Most of the provinces in the East, the central area of the scale of investment in education on promoting economic growth effect is slightly higher than other provinces and cities.

The provinces of our country higher human capital contribution rate is not high. Investment in education quality is still at a low level to promote economic growth.

Unfair degree of regional education investment hinder economic growth. West East, middle obvious inhibitory effect.

\section{ACKNOWLEDGMENT}

This research was supported by the funds from:

1. The construction of key projects of Fujian province serving Haixi "Haixi port logistics information platform construction", Project Number: A103.

2. Construction Funds of Master Degree Awarded Unit of Quanzhou Normal University.

3. Construction Funds of High Educational Engineering Research Center of of Fujian Pronvince for E-Commerce Intelligent Based on Cloud Computing and Internet of Things;

4. Fujian province education department 2012JK project (number JK2012041): The applications of cloud computing and internet of things in the enterprise information public service platform.

\section{REFERENCES}

[1].Jianwen Yuan, analysis of the impact of education on economic development, "northern" 2006 the 08 period P261

2].xuejun Bie, the role of science and technology education in economic development, "education and economy" in 200001

[3] Schultz, "human capital investment" [M], Beijing Economic College Press, 1992.

[4]Zengzheng Cai, "measuring the contribution of education to economic growth -- Empirical Analysis Based on the strategy of rejuvenating the country through science" [J], economic research, 1999 (2): 39-48.

[5] Maolin Ye , Xiaoqi Zheng, "measuring the contribution of education to economic growth of" [J], "study" economic technology, 2003 (1): 89-92.

[6] Shufen Wang , "' quantitative research on the coordinated development of the national hundred county education and economic [J], "statistics and decision", 2007 (4): 86-88.

[7] Yunzhong Liu , Yingmei Xu , "the education gap between urban and rural areas and the education gap between urban and rural residents cointegration study" [J], "education and economy", 2007 (4): 42-46.

[8]Shuhui Wu, "analysis" empirical relationship between education 
expenditure and economic growth in East China [J], "economics of education research in 2010:", pp. 178-179.

[9]Jing Qu , China's education investment to economic growth analysis of [J] "statistics and decision" in 201321

[10].Zhihua Lai , Bifeng Wang, "the spatial heterogeneity of educational output structure on economic growth effect of economic and management"[J] in 201212

[11].Yan Chen , Jianchun Gu , Hunan human resource allocation and adjustment of higher education structure $[\mathrm{J}]$ Journal of Changsha University; in 200801

[12].Yanling Xiao,Ning Wang ,Yu Li ,Donghong Yang , Heilongjiang province regional higher education and economic development of the interaction [J] Journal of Daqing Petroleum Institute; in 200901

[13]. Junlan Cai , an empirical analysis Chinese [J] development scale of higher education and economy; higher education exploration; 200803 [14].Quanzhi Yan ,Wenyan Miao , the Henan Province ordinary higher education and economic development coordination analysis $[\mathrm{J}]$; social science of Henan in 200703 